\title{
Salon
}

\section{Requiem for the sounds of silence}

$\mathrm{D}$ uring my annual reflection on the occasion of President John F. Kennedy's assassination, I serendipitously stumbled on the moving poetry from Paul Simon's signature song, The Sounds of Silence. It happens, ironically - and previously unbeknownst to me - that this moving elegy was composed during Simon's period of mourning after Kennedy's assassination. The last stanza speaks eloquently to the sounds that now reverberate in this maturing cardiologist's mind:

And the people bowed and prayed

To the neon god they made

And the sign flashed out its warning

In the words that it was forming

And the sign said, "The words of the prophets are written on the subway walls

And tenement halls"

And whispered in the sounds of silence. ${ }^{1}$

Silence seems increasingly hard to come by more than 4 decades later. Multiple forces conspire to fill whatever gaps in life's cacophony have the temerity to appear. Quiet contemplation, private conversation, let alone chance dialogue between strangers is almost extinct amidst anonymous silos replete with the endless barrage of noise, commercialism and the invasion of television, cellular telephones, iPods and the Internet. Paul Simon's later reflections on his ballad's meaning were that it represented "a societal view of a lack of communication." This stands as a remarkably prescient and contemporary insight.

In medicine, history taking and the clinical examination have nearly vanished in major academic medical centres, where the dominance of technology has markedly attenuated meaningful rapport between physicians and patients that comprises the traditional bedrock of clinical medicine. Focusing on the stories that sick people tell has become a lost art amidst the multiple conversations emanating from the cadre of health care personnel who descend on the bedside carrying beepers, cell phones, and Blackberries that guarantee multiple uncensored and, usually, irrelevant interruptions. The allowance for pregnant silences to naturally unfold between patients and physicians, once a time honored vehicle for facilitating rich, nonverbal communication and opportunities for spontaneous combustion is a distant memory. Conversational pauses are rarely permitted in the presence of well-meaning family or the legions of allied health care workers clustered at the bedside.

Admitedly, silence in medicine can cut both ways, and may leave disaster and unhappiness in its wake. Failure to communicate truthfully (and compassionately) the substance of an accurate diagnosis containing devastating potential personal implications, failure to honestly communicate medical errors and failure to express a simple thank you, all signal lost opportunities for positive contributions.

But, on the plus side, silence not only creates a framework for listening, it is also the required currency for hearing. Perhaps the most difficult clinical skill for a young physician to acquire is auscultation. Although the stethoscope remains a widely recognizable tool of the physician, its utility as a meaningful diagnostic instrument has nearly vanished amongst the clinical repertoire of most physicians. The ability to listen intelligently with the right side of the stethoscope, in the right place and position, at the right time, for the right thing may yield remarkable insight into the state of the heart's function as well as that of the cardiac valves and rhythm, yet such knowledge rarely reaches examining ears let alone documentation in the medical record.

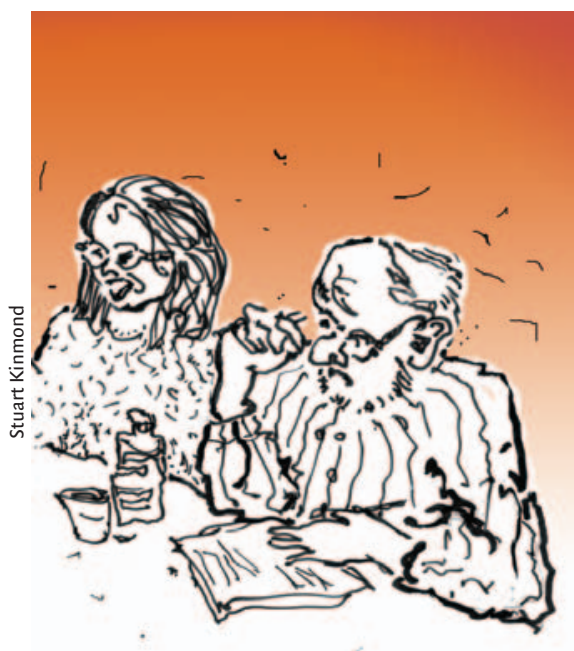

As medicine enthusiastically caroms headlong into the exciting arenas that lie ahead, we would be well advised to preserve the sounds of silence. In the future, there is likely to be even greater need for tranquility, meaningful reflection and respite. Relief from the information barrage of the contemporary world will surely be a welcome refuge that is increasingly valued at a time when both listening and hearing sound perilously distant.

\section{Paul W. Armstrong MD \\ University Professor \\ Division of Cardiology \\ University of Alberta \\ Edmonton, Alta.}

\section{REFERENCE}

I. Simon P, Garfunkel A. The sounds of silence. On: Sounds of silence. New York: Columbia Records; I966.

Have you got an opinion about this article? Post your views at www.cmaj.ca. Potential Salon contributors are welcome to send a query to salon@cma.ca. 